\title{
Strategi Kampanye Joko Widodo dan Ma'ruf Amin dalam Debat Calon Presiden pada Tahun 2019
}

\section{The Campaign Strategy of Joko Widodo and Ma'ruf Amin in the Presidential Candidate Debate in the 2019}

\author{
Ribkha Annisa Octovina, Leo Agustino \& Dede Sri Kartini* \\ Program Studi Ilmu Politik, Universitas Padjadjaran, Bandung Indonesia
}

Diterima: 11 Agustus 2021; Direview: 11 Agustus 2021; Disetujui: 29 Desember 2021 \begin{abstract}
Abstrak
Artikel ini bertujuan untuk menggambarkan strategi kampanye politik Joko Widodo dan Ma'ruf Amin dalam debat calon presiden pada pemilihan presiden tahun 2019. Masalah difokuskan pada strategi kampanye yang dilakukan oleh partai PDI Perjuangan untuk mendukung agende dabat politik terhadap calon presiden Joko Widodo dan Ma'ruf Amin. Guna mendekati masalah ini dipergunakan acuan teori dari Nursal menggunakan teori strategi kampanye politik. Adapun keterpilihan teori tersebut dalam penelitian ini karena lebih sesuai untuk mendeskripsikan temuan strategi kampanye politik pada pasangan calon Joko Widodo dan Ma'ruf Amin dalam debat calon presiden 2019 yang bisa menarik simpati atau memperoleh dukungan seperti telah diuraikan pada studi pendahuluan. Data-data dikumpulkan melalui wawancara dan dianalisis secara kualitatif. Kajian ini menyimpulkan bahwa pada pelaksanaan debat calon presiden dalam pemilihan presiden Tahun 2019 strategi kampanye politik yang diterapkan PDI Perjungan untuk mendukung Joko Widodo dan Ma'ruf Amin salah satunya adalah pemasaran produk politik melalui media massa. Pertama, melakukan penguatan pada materi. Kedua, melakukan pengamatan terhadap target serta menentukan target terhadap debat politik. Ketiga, melakukan pendekatan kepada media.

Kata Kunci: Strategi Politik; Debat Politik; Pemilihan Presiden
\end{abstract}

\begin{abstract}
This article aims to describe the political campaign strategy of Joko Widodo and Ma'ruf Amin in the presidential candidate debate in the 2019 presidential election. The problem is focused on the campaign strategy carried out by the PDI-P party to support the political debate agenda against the presidential candidates Joko Widodo and Ma'ruf Amin. In order to approach this problem, Nursal's theoretical reference is used to use the theory of political campaign strategy. The selection of this theory in this study is because it is more suitable to describe the findings of political campaign strategies for the candidate pairs Joko Widodo and Ma'ruf Amin in the 2019 presidential candidate debate that can attract sympathy or gain support as described in the preliminary study. The data were collected through interviews and analyzed qualitatively. This study concludes that in the implementation of the presidential candidate debate in the 2019 presidential election, the political campaign strategy applied by PDI Perjungan to support Joko Widodo and Ma'ruf Amin, one of which is the marketing of political products through the mass media. First, strengthen the material. Second, observing the target and determining the target for the political debate. Third, approach the media throughout the media, including media that are affiliated and unaffiliated.
\end{abstract}

Keywords: Political Strategy; Political Debate; Presidential Election

How to Cite: Octovina, R.A., Agustino, L, \& Kartini, D.S., (2022), Strategi Kampanye Joko Widodo dan Ma'ruf Amin dalam Debat Calon Presiden pada Tahun 2019, PERSPEKTIF, 11 (1): 385- 393 
Ribkha Octovina, Leo Agustino \& Dede Sri Kartini, Strategi Kampanye Joko Widodo dan Ma'ruf Amin dalam Debat Calon Presiden pada Tahun 2019

\section{PENDAHULUAN}

Pemilihan Presiden Indonesia pada 17 April 2019, di ikuti oleh dua kandidat Calon Presiden dan Calon Wakil Presiden antara lain yaitu calon 01 yaitu Joko Widodo dengan calon 02 yaitu Prabowo Subianto. Pemilihan Presiden selalu berupaya untuk menarik masyarakat agar berpartisipasi dalam memilih calonnya melalui aktivitas politik. Aktivitas politik yang dimaksud meliputi kampanye melalui audio (radio) maupun visual (televisi) serta media lainnya seperti spanduk, media massa cetak, pamflet, selebaran dan juga komunikasi antar pribadi yang berbentuk face to face (tatap muka) atau lobby yang berisi penyampaian pesan mengenai program, platform, asas, ideologi serta janji-janji politik lainnya. Aktivitas politik dilakukan untuk meyakinkan pemilih sehingga pada pencoblosan bisa menentukan pilihannya terhadap salah satu partai politik yang menjadi peserta pemilihan umum untuk mewakilinya dalam badan legislatif maupun eksekutif (Rahman, 2007).

Pada pelaksanaan aktivitas politik, komunikasi politik memiliki fungsi yang penting dan berpengaruh. Almond dan Powell (dalam Lely, 2010) mendefinisikan suatu proses komunikasi politik sebagai fungsi politik yang sama-sama membangun fungsi dalam melakukan kegiatan kegiatan politik yang bertujuan mencapai kekuasaan.

Perencanaan dan strategi merupakan hal yang penting karena menentukan kemenangan calon dalam proses pemilu (Fatimah, 2018). Tidak mengherankan jika dalam momentum Pemilu, pihak penyelenggara selalu berupaya melakukan kegiatan kampanye, penyuluhan dan sosialisasi kepada berbagai kalangan masyarakat agar datang ke tempat pemungutan suara. Hal tersebut tidaklah lain untuk meningkatkan partisipasi masyarakat dalam pemilu, sebab Indonesia menganut sistem politik demokrasi langsung. Sederhananya, dalam konteks pemilu, sistem politik demokrasi langsung akan menjadi semakin mapan apabila masyarakat ikut andil mengambil peran dalam kegiatan memilih pemimpin sesuai dengan pilihan secara jujur, adil dan terbuka.

Kampanye adalah suatu usaha dalam melakukan komunikasi politik untuk mendukung pesta pemilihan umum (pemilu), kampanye adalah suatu cara guna memperkenalkan diri serta memaparkan sebuah visi dan misi tentang kebijakan pembangunan daerah selama lima tahun berlangsung. Kampanye politik adalah periode yang diberikan oleh panitia pemilu kepada semua kontestan, baik partai politik atau perorangan, untuk memaparkan programprogram kerja dan memengaruhi opini publik sekaligus memobilisasi masyarakat agar memberikan suara kepada mereka sewaktu pencoblosan (Lilleker \& Negrine, 2000).

Waktu kampanye yang diberikan oleh Komisi Pemilihan Umum (KPU) ialah minim sehingga memaksa pasangan calon kepala daerah bersama tim sukses kampanyenya untuk mengatur strategi kampanye politik yang efektif supaya bisa menjangkau seluruh lapisan masyarakat didaerah pemilihannya.

Undang-Undang Republik Indonesia No. 42, pasal 1 ayat (22) Tahun 2008 Tentang Pemilihan Umum Presiden dan Wakil Presiden "kampanye Pemilu Presiden dan Wakil Presiden, selanjutnya disebut Kampanye, adalah kegiatan untuk meyakinkan para Pemilih dengan menawarkan visi, misi, dan program Pasangan Calon". Calon Presiden dan Calon Wakil Presiden dalam menyampaikan visi, misi dan program menggunakan bahasa politik. Darma (2009) mengatakan bahwa bahasa politik adalah bahasa yang digunakan sebagai alat politik, bahasa pejabat pemerintahan dalam berpidato yang berbau politik tentu saja semua bahasa yang digunakan mengandung maksud atau tujuan tertentu.

Proses pemilihan Presiden disampaikan dengan kampanye politik salah satunya dengan debat Calon Presiden untuk menyampaikan argumen dan gagasannya mengenai visi dan misi pemerintahan mendatang. Debat merupakan salah satu peristiwa komunikasi. Martel (dalam Perloff, 1998) Mendefinisikan debat kampanye politik sebagai penampilan bersama dua atau lebih kandidat yang berlawanan, yang menempati posisinya masingmasing, dengan pernyataan yang langsung untuk memperoleh dukungan tanpa adanya interupsi. Definisi ini lebih mendekati pada debat politik karena adanya pertemuan dalam satu tempat, face to face, dan diskusi.

Debat calon presiden dan wakil presiden yang diselenggarakan KPU dari 17 Januari hingga 13 April 2019 memiliki sebanyak lima putaran debat. Berbeda dengan penyelenggaraan sebelumnya, dalam debat capres cawapres ini, kedua pasangan calon akan 
terlebih dahulu menerima daftar pertanyaan yang akan diajukan panelis beberapa hari sebelum dilaksanakan debat tersebut. Hal ini berdasarkan persetujuan kedua tim sukses. Melalui debat calon presiden 2019 tersebut diharapkan pemirsa atau calon pemilih bisa mengetahui kualitas, penguasaan permasalahan, visi, konsep, program konkret dan seterusnya dari masing-masing kandidat.
Dari pengetahuan hasil penilaian performa sebenarnya masing-masing kandidat tersebut. Calon pemilih bisa tanpa ragu menentukan pilihannya demi tercapai kemajuan bersama bagi bangsa dan tanah air Negara Kesatuan Republik Indonesia (NKRI) , di bawah pimpinan presiden dan wakil presiden selama 5 tahun dari 2019- 2024 berikut rincian debat capres tahun 2019:

Tabel 1 Jadwal dan Tema Debat Pilpres 2019

\begin{tabular}{cc}
\hline Jadwal Debat & Tema Debat \\
\hline Debat Pertama & Hukum dan HAM \\
17 Januari 2019 & Korupsi \\
& Terorisme \\
\hline Debat Kedua & Energi dan Pangan \\
17 Februari 2019 & Sumber Daya Alam dan Lingkungan Hidup \\
& Infrastruktur \\
\hline Debat Ketiga & Pendidikan \\
17 Maret 2019 & Kesehatan \\
& Ketenagakerjaan \\
& Sosial dan Kebudayaan \\
\hline Debat Keempat & Ideologi \\
30 Maret 2019 & Pemerintahan \\
& Pertahanan dan Keamanan \\
& Hubungan Internasional \\
\hline Debat Kelima & Ekonomi dan Kesejahteraan Sosial \\
& Keuangan dan Investasi \\
& Perdangangan dan Industri \\
\hline
\end{tabular}

Sumber: Tirto.id "Jadwal Lengkap dan Tema Debat Pilpres 2019"

Kelima debat ini bertujuan untuk membuka pikiran dan menentukan pilihan rakyat Indonesia terhadap calon pemimpin bangsa. Selain itu bisa menjadi rana untuk melihat kesiapan calon presiden dan wakil presiden bertarung visi dan misi mereka. Dua pasangan calon dengan nomor urut 01 Joko Widodo dan Maaruf Amin dan pasangan calon nomor urut 02 Prabowo Subianto dan Sandiaga Uno. Dua pasangan calon ini menjadi representasi pemilihnya. Yaitu melalui debat sebagai etalase pemilihan presiden pada 17 April 2019. Debat yang telah diselenggarakan selama lima kali ini menjadi perbincangan hangat masyarakat Indonesia tentu saja karena peran media massa baik radio, televisi, majalah, surat kabar dan media online sangat besar. Fungsi keluaran terkait dengan dampak yang dihasilkannya (Mas'oed, 1982).

Debat politik pada masyarakat demokrasi seperti Amerika, berbeda dengan dengan di Indonesia. Amerika bisa menyampaikan segala hal dengan sebebasnya. Label terorisme yang melekat pada imigran diberikan oleh Donald
Trump dan disampaikan secara konsisten dalam berbagai kesempatan, seperti pada debat presiden, wawancara, konferensi pers, dan lainnya (Beland, 2018). Isi debat calon presiden juga saling menuduh dan menyerang. Hal ini menjadi sangat spektakuler di Amerika. Sedangkan dalam negara demokrasi seperti Indonesia, debat bisa menyampaikan informasi sebebasnya, akan tetapi diikat oleh normanorma dan nilai-nilai yang ada dalam masyarakat itu sendiri.

Pada pemilu presiden tahun 2014, debat sebagai salah satu bentuk dari komunikasi politik yang melibatkan 3 elemen komunikasi politik yaitu: tim sukses Jokowi-JK, media massa, dan warga negara Indonesia. Mc Nair (2010) berpendapat, ada tiga elemen dalam komunikasi politik, yaitu: organisasi politik, media, dan warga negara. Debat pilpres 2014 lalu merupakan ajang bagi Jokowi-JK menampilkan program-program kerja dalam kampanye Pilpres 2014 melalui media massa khususnya televisi. Sebagai komunikator politik Jokowi-JK melakukan (Impression 
Ribkha Octovina, Leo Agustino \& Dede Sri Kartini, Strategi Kampanye Joko Widodo dan Ma'ruf Amin dalam Debat Calon Presiden pada Tahun 2019

management) pengelolaan kesan untuk menunjukkan gambar diri yang akan diterima oleh khalayak. Goffman dalam Mulyana (2010) mengasumsikan bahwa ketika orang-orang berinteraksi, mereka ingin menyajikan suatu gambaran-diri yang akan diterima orang lain dan upaya ini disebut sebagai "pengelolaan kesan" (impression management), yakni teknikteknik yang digunakan aktor untuk memupuk kesan-kesan tertentu.

Strategi kampanye yang baik harus memiliki tujuan yang pasti, maka dari itu perlu dipastikan proses komunikasi politik dalam kampanye harus berjalan dengan baik dan menghasilkan efek yang maksimal (Wahid, 2016). Agar tujuan kampanye politik bisa berjalan sesuai dengan harapan, maka tim pemenangan dalam kampanye politik perlu melakukan iklan politik dengan tujuan para calon tokoh politik tersebut bisa dikenal oleh khalayak.

Sebagai aktor politik atau pemimpin dalam politik sangat penting untuk bisa membentuk citra politik dirinya melalui komunikasi politik dalam menciptakan stabilitas sosial dan memenuhi tuntutan masyarakat di dalam komunikasi politik, proses pembentukan citra politik bisa dipraktekkan dengan cara mengemas pesan politik yang kemudian disebarkan kepada masyarakat. Juga keberadaan media massa, media sosial bisa dijadikan bagian dari instrumen pembentukan dan penyampaian pesan politik. Cara seperti ini yang disebut Stayer (dalam Danial, 2009) yaitu bagian dari cara baru dalam mengkomunikasikan politik Melaksanakan kampanye menggunakan media, tentu banyak dilakukan` oleh para politisi, terutama mereka mengandalkan media massa dan media sosial.

Pada umumnya, dalam perhelatan pemilu, segala bentuk mulai dari pencitraan, penyusunan pesan politik, memerlukan strategi kampanye yang baik untuk memperoleh dukungan. Pada konteks penelitian ini, peneliti memiliki satu tema besar yakni komunikasi politik. Kemudian pada tema besar tersebut peneliti spesifikkan pada aspek kampanye sehingga menjadi strategi kampanye politik pada debat calon presiden tahun 2019 . Sudah barang tentu dalam spesifik ini merupakan bagian penyederhanaan strategi politik dari berbagai sudut pandang, yang jika dikaji lebih jauh lagi memiliki hierarki makna dan esensitas lebih luas.

Peneliti melakukan analisis mengenai strategi kampanye politik dalam debat calon presiden pada pemilihan presiden tahun 2019 dengan menggunakan teori strategi kampanye politik. Adapun keterpilihan teori tersebut dalam penelitian ini karena lebih sesuai untuk mendeskripsikan temuan strategi kampanye politik pada pasangan calon Joko Widodo dan Ma'ruf Amin dalam debat calon presiden 2019 yang bisa menarik simpati atau memperoleh dukungan seperti telah diuraikan pada studi pendahuluan.

Beberapa hasil penelitian terdahulu yang bersinggungan dengan topik pada penelitian ini yakni; Strategi Kampanye Politik Joko Widodo dan Ma'ruf Amin dalam Debat Calon Presiden pada Pemilihan Presiden Tahun 2019 adalah sebagai berikut:

Pertama, hasil penelitian Fatimah (2018) dalam Kampanye sebagai Komunikasi Politik: Esensi dan Strategi dalam Pemilu memperoleh temuan bahwa dalam Negara demokrasi peran kampanye politik sangat vital sebagai proses memperkenalkan kandidat kepada masyarakat. Kita memahami esensitas kampanye politik sebagai upaya terorganisir guna mempengaruhi proses pengambilan keputusan pada kelompok tertentu yang memiliki tujuan untuk memenangkan pemilu, dengan demikian setiap calon perlu mempertimbangkan strategi, planning yang komprehensif dan optimal. Strategi dan perencanaan ini sangat penting karena menentukan orientasi kemenangan calon dalam proses pemilu. Meski demikian, kita juga kadang melihat upaya-upaya yang mungkin kurang sehat dalam proses praktik kampanye politik tersebut yakni kampanye yang dilakukan oleh calon sering diwarnai dengan upaya untuk menjatuhkan lawan, atau bisa disebut kampanye hitam.

Kedua, hasil penelitian Saputra (2010) dalam Pengaruh Tayangan Debat Capres dan Cawapres Dengan Keputusan Memilih Capres pada Pilpres 2009 memperoleh temuan bahwa mayoritas responden cenderung menyetujui tayangan debat kandidat presiden berdampak pada keputusan khalayak berdasarkan aspek kredibilitas, daya tarik, kesamaan, serta kekuatan komunikator dengan bahan evaluasi memutuskan memilih dan tayangan debat kandidat menyampaikan pesan komunikasi politik oleh komunikator berhubungan searah 
pengambilan keputusan pemilih kandidat, dan tayangan debat kandidat turut menyumbang sebesar $91 \%$ bagi tercapainya khalayak dalam memilih.

Ketiga, hasil penelitian Evi Kurnia Sari (2015), yang tersebut menjelaskan tentang deskripsi dan analisis strategi kampanye politik Gabungan Relawan Jokowi-JK kaltim dalam pemilihan presiden tahun 2014 di Kota Samarinda yang difokuskan pada sejarah formasi dan konfigurasi Gabungan Relawan Jokowi-JK Kaltim, strategi kampanye politik Gabungan Relawan Jokowi-JK Kaltim dalam pemilihan presiden di Kota Samarinda, Strategi yang paling menentukan keberhasilan Gabungan Relawan Jokowi-JK Kaltim dalam pemilihan presiden tahun 2014 di Kota Samarinda. Strategi kampanya politik gabungan relawan Jokowi-JK Kaltim meliputi: menyatukan visi relawan, pembagian dan fungsi relawan, pendekatan persuasif serta pencitraan calon.

Penting dan menariknya penelitian mengenai debat calon presiden pada pemilihan presiden tahun 2019 ini di antaranya adalah bagaimana strategi kampanye politik dalam debat politik calon presiden. Belum ada penelitian yang membahas secara mendalam perihal strategi kampanye politik pada debat calon presiden yang memungkinkan adanya dan peningkatan partisipasi dan atau perubahan dukungan pada kontestasi pemilu terhadap pasangan calon atau kandidat. Dengan demikian peneliti memiliki ketertarikan untuk mengkaji lebih dalam lagi.

\section{METODE PENELITIAN}

Penelitian tentang strategi kampanye politik pada debat calon presiden tahun 2019 menggunakan metode penelitian kualitatif. Penelitian kualitatif merupakan suatu pendekatan ekplorasi untuk memahami latar belakang masalah suatu fenomena yang menjadi isu penelitian. Penelitian kualitatif mengutamakan proses deskriptif analisis untuk mengetahui hasil dari kajian yang akan dilakukan (Creswell, 2010).

Dalam penelitian ini menggunakan metode kualitatif deskriptif. Peneliti mencari data, fakta-fakta empiris yang terjadi di lapangan dan berusaha mendeskripsikan data yang dibisakan selama proses penelitian. Peneliti menggunakan metode kualitatif deskriptif karena dalam kampanye politik pada debat calon presiden tahun 2019 peneliti ingin bagaimana strategi yang digunakan. Peneliti akan mengumpulkan data pada informaninforman, berita, naskah dan sebagainya, kemudian mendeskripsikan temuan-temuan tersebut dan menyusun sebaik mungkin. Metode ini cocok bagi penelitian peneliti untuk membantu mendeskripsikan temuan-temuan lainnya nanti.

Adapun pengumpulan data dengan teknik ini adalah mengadakan tanya jawab secara langsung baik secara lisan maupun secara tertulis kepada pihak-pihak yang berkaitan dengan masalah yang diteliti. Dalam penelitian ini, pedoman wawancara yang digunakan adalah peneliti membuat dan menyusun sendiri pertanyaan-pertanyaan yang akan diajukan kepada informan.

\section{HASIL DAN PEMBAHASAN}

Peneliti di sini akan menganalisis strategi kampanye politik pada debat calon presiden tahun 2019 dengan menggunakan teori strategi kampanye politik. Strategi kampanye politik merupakan sebuah taktik yang begitu berperan dalam pemenangan pemilihan umum. Keberhasilan strategi kampanye politik memberikan sebuah kontribusi yang besar dalam menggunakan dan merencanakan strategi calon presiden atau partai politik untuk menyusun dalam menghadapi pemilu. Politik dan strategi, kedua hal tersebut harus berjalan beriringan apabila mengejar tujuan berpolitik dalam pemenangan pemilihan presiden 2019. Sementara itu strategi juga membutuhkan taktik, prasyarat dalam sebuah perencanaan taktik adalah adanya perencanaan strategi. Perencanaan taktik dan pengambilan tindakan hanya bisa memiliki arti apabila sebuah strategi direncanakan secara teliti. Jadi perencanaan taktik bisa memberikan jawaban atas pertanyaan siapa, akan melakukan apa, kapan, di mana, bagaimana dan mengapa.

Menurut Nursal (dalam Firmanzah, 2012) terbisa beberapa strategi kampanye salah satunya adalah pemasaran produk politik melalui media massa (pull political marketing). Melalui media promosi, iklan, konferensi pers, talk show dan debat publik, partai politik atau kandidat perseorangan bisa meningkatkan ketersediaan informasi yang nantinya sangat dibutuhkan oleh pemilih dalam menentukan kandidat mana yang akan dicoblos. Pull marketing adalah strategi yang paling banyak 
Ribkha Octovina, Leo Agustino \& Dede Sri Kartini, Strategi Kampanye Joko Widodo dan Ma'ruf Amin dalam Debat Calon Presiden pada Tahun 2019

digunakan oleh partai dan kandidat. Penyampaian pesan pada strategi ini dilakukan melalui media massa baik elektronik, cetak, luar ruang, mobile dan Internet.

Berdasarkan wawancara dengan Kepala Biro Analisis Dan Kajian Strategi Badan Pendidikan Dan Pelatihan Pusat DPP PDI Perjuangan, Utomo (2021), partai dalam mempersiapkan debat calon presiden Joko Widodo dan Ma'ruf Amin tahun 2019 membentuk tim khusus yang tugasnya adalah menyiapkan materi. Proses pelaksanaan persiapan materi pada Partai PDI Perjuangan adalah sebagai berikut: 1) Melaksanakan diskusi besar untuk menyiapkan materi yang akan dibahas pada debat capres; 2) Mengirimkan materi debat kepada tim yang memang terdiri dari ahli ahli untuk kemudian di pertajam; 3) Memberikan materi yang telah menbisakan masukan dari ahli diberikan kepada tim inti yang mendampingi untuk kemudian disampaikan oleh paslon saat debat berlangsung; 4) Melakukan simulasi untuk menyampaikan data-data tersebut.

Pada debat politik dibutuhkan tingkat pemahaman tertentu akan kondisi nasional untuk bisa mengikuti arah dan proses diskusi (Firmansyah, 2012). Ketidakmampuan dalam mempertahankan ide dan gagasan politik selama debat publik hanya akan menurunkan reputasi dan image kontestan tersebut.

Seiring dengan meningkatnya penggunaan image politik sebagai salah satu sarana untuk memenangkan persaingan antarpartai, konsekuensi logisnya adalah persaingan dalam membangun image (Firmansyah, 2010). Masing-masing partai politik akan berusaha memperkuat image yang telah ada. Dengan kata lain, partai akan semakin memantapkan posisi dan identitas mereka. Intensitas persaingan yang sangat tinggi tidak menutup kemungkinan munculnya perilaku-perilaku yang dengan sengaja ingin menghancurkan reputasi partai politik atau kandidat individu. Dengan rusaknya image partai politik atau kandidat individu tertentu, kekosongan image yang diidolakan masyarakat tersebut bisa diisi oleh partai politik lain.

Strategi pull marketing menitikberatkan pada pembentukan image politik yang positif. Supaya simbol dan image politik bisa memiliki dampak yang signifikan, kedua hal tersebut harus mampu membangkitkan sentiment. Hal ini dilakukan karena pemilih cenderung memilih partai atau kontestan yang memiliki arah yang sama dengan apa yang mereka rasakan. Maka diperlukan strategi untuk bisa menjawab pertanyaan debat dan menarik simpatisan.

Strategi dilaksanakan PDI Perjuangan dalam debat politik calon presiden Joko Widodo dan Ma'ruf Amin tahun 2019 secara keseluruhan sebenarnya sama seperti pada umumnya yaitu dengan menyesuaikan dengan target (Utomo, wawancara, 2021). Efektivitas penyampaian pesan kepada masyarakat harus melihat kondisi masyarakatnya. Maka terbisa perlakuan yang berbeda sesuai dengan target pemilihnya khususnya kaum milenial, kaum awam dan juga masyarakat kita yang belum menentukan partai politik pilihan politiknya (Utomo, wawancara, 2021).

Di zaman yang serba digital, banyak generasi muda dinilai mampu untuk membawa perubahan. Tentunya bila kita mendekati kaum milenial yang kita anggap wawasannya lebih luas dan pasti sudah tersentuh gadget (Utomo, wawancara, 2021). Menurut hasil Survei Sosial Ekonomi Nasional (Susenas) Tahun 2019, jumlah pemuda sebesar 64,19 juta jiwa atau seperempat dari total penduduk Indonesia. Bersdasarkan distribusi menurut wilayah, lebih dari separuh pemuda terkonsentrasi di Pulau Jawa (52,28 persen) (Amannullah, 2019). Hal tersebut menjadi pertimbangan partai politik untuk memilih pemuda untuk meningkatkan suara Partai. Generasi muda adalah salah satu domain yang paling menarik diperbincangkan, apalagi ketika dikaitkan dengan politik praktis seperti pemilihan umum. Tentu hal tersebut menjadi alasan besar bagi partai politik untuk menjadikan pemuda sebagai target.

Pendekatan juga dilakukan dengan target undecided voters. Hasil survei terbaru Konsepindo Research and Consulting menunjukkan masih ada 11,1 persen pemilih belum menentukan pilihannya di Pemilu 2019 (Suara, 2019). Menurut Utomo (2021), masyarakat yang belum menentukan pilihannya bisa terjadi karena ketidaktahuannya atau ketiadaan sambungan atau hubungan kekerabatan dari orang tua maupun dari keluarganya contohnya seperti si A memilih satu partai politik dikarenakan orang tuanya merupakan pengurus partai tersebut sehingga untuk memilih partai lain itu kecil. Terhadap A, strateginya akan berbeda dengan si B yang tidak berafiliasi dengan partai 
manapun. Maka strategi PDI Perjuangan dalam debat politik calon presiden Joko Widodo dan Ma'ruf Amin tahun 2019 akan disesuaikan dengan target siapa dan seperti apa tujuan yang ingin dicapai (Utomo, 2021).

Terhadap masyarakat desa partai melakukan pendekatan dengan mendatangi mereka satu persatu gadget (Utomo, wawancara, 2021). Dalam masyarakat yang mayoritas tinggal di pedesaan, pemberitaan melalui koran dan majalah akan kehilangan efektivitasnya (Firmansyah, 2010). Tidak banyak orang desa yang meluangkan waktu untuk membaca koran dan majalah. Maka, debat politik yang ditayangkan melalui TV juga kurang efektif untuk masyarakat desa.

Kepala Biro Analisis dan Kajian Strategi Badan Pendidikan Dan Pelatihan Pusat DPP PDI Perjuangan menyampaikan strategi terhadap masyarakat desa PDI Perjuangan dalam debat politik calon presiden Joko Widodo dan Ma'ruf Amin tahun 2019 mengatakan sebagai berikut: "Terhadap orang-orang yang bisa kita katakan tinggal didaerah pinggiran bisa dipastikan kemungkinan besar mereka tidak menonton debat karena menurut mereka kurang menarik hal ini disebabkan karena mereka tidak tersentuh media dengan baik. Sampai sejauh ini konstituen yang memang paham betul mengenai paratai politik bisa dikatakan hanya sebesar 30\% sementara kalangan yang 70\% bisa dikatakan pragmatis atau mengikuti saja siapa yang paling banyak di dukung (Utomo, wawancara, 2021)"

Berbeda dengan masyarakat di pedesaan, masyarakat perkotaan lebih individualistik dengan semangat kekeluargaan terbatas pada keluarga terdekat saja. Kebanyakan waktu akan dihabiskan pada aktivitas masing-masing individu yang sudah menyita banyak waktu dan enerji (Firmansyah, 2010). Dengan struktur masyarakat seperti ini, strategi media komunikasi politik juga harus menyesuaikan diri.

Media seperti radio, koran dan majalah bisa digunakan untuk membawa pesan politik. Selain itu, jumlah masyarakat yang terdidik di perkotaan lebih banyak relatif dibandingkan dengan di pedesaan, sehingga pemahaman mereka tentang permasalahan bangsa dan negara juga lebih baik. Pada debat capres sasaran besarnya adalah kalangan yang well educate (Utomo, wawancara, 2021). Jadi, acara seperti debat dan diskusi politik akan lebih sesuai untuk ditargetkan kepada masyarakat perkotaan.

Selain menentukan dan memasang strategi kepada target partai politik juga menyentuh media. Salah satu kunci dalam persaingan image politik adalah media massa. Media massa ini diartikan sebagai suatu entitas yang memiliki peran dan fungsi untuk mengumpulkan sekaligus men distribusikan informasi dari dan ke masyarakat (Firmansyah, 2010). Komunikasi politik tidak bisa dilakukan oleh partai politik sendirian. Efektivitas komunikasi politik membutuhkan peran serta media massa, karena merekalah salah satu profesi penting yang memiliki perangkat dan kemampuan berkomunikasi dengan masyarakat luas. Komunikasi politik kerapkali terjadi secara tidak langsung melalui pemberitaan-pemberitaan yang dilakukan oleh media massa. Dalam hal ini, rekan-rekan wartawan dan media massa harus dijadikan partner strategis bagi partai politik untuk mengkomunikasikan program kerja dan semua hal yang telah mereka lakukan.

Mengenai strategi terhadap media, dalam debat politik calon presiden Joko Widodo dan Ma'ruf Amin tahun 2019, Kepala Biro Analisis dan Kajian Strategi Badan Pendidikan Dan Pelatihan Pusat DPP PDI Perjuangan mengatakan sebagai berikut: "Sekarang ini media itu dikelola sebagai industri artinya media itu harus menguntungkan. Kita tahu di Indonesia ini hampir semua media itu dimiliki oleh kebetulan juga media media besar itu mempunyai afiliasi. Media ini adalah alat yang paling efektif untuk bisa menyampaikan infoinfo kampanye dengan memberikan stimulant ataupun daya tarik kepada target sasaran yang mendukung. Kepada media kita jadi kita benarbenar baik dengan mereka jangan sampai membuat mereka "tidak nyaman" atau kitanya tidak welcome meskipun katakanlah kemedia itu kita tau kebetulan pemiliknya itu berafiliasi dengan yang sebelah ya itu biasa ga apa apa. Ketika itu media media mainstream yang besar ada dipihak kita seperti yang kita sebutkan, terus terang kaya media Indonesia metro TV ada di koalisi kita di NASDEM ga mungkin dong NASDEM akan tidak mendukung dan tidak menyiarkan yang baik baik (Utomo, wawancara, 2021)."

Melalui jaringan media massa, pesan akan bisa dengan mudah menjangkau masyarakat yang lebih luas. Kondisi seperti ini membuat 
Ribkha Octovina, Leo Agustino \& Dede Sri Kartini, Strategi Kampanye Joko Widodo dan Ma'ruf Amin dalam Debat Calon Presiden pada Tahun 2019

persaingan untuk menbisakan akses ke media massa menjadi sangat tinggi. Semua pihak merasakan pentingnya peran dan kontribusi media massa sebagai institusi yang mengkomunikasikan aktivitas partai. Oleh karena itu, semua pihak akan bersaing untuk menbisakan akses pemberitaan media massa. Pemberitaan yang intensif akan bisa dengan mudah menciptakan public-awareness. Publik akan bisa dengan cepat mengetahui apa saja yang telah dilakukan partai-partai politik. Pada gilirannya, hal ini akan bisa dengan mudah memengaruhi opini publik.

Mengenai informasi yang disampaikan media dalam debat politik calon presiden Joko Widodo dan Ma'ruf Amin tahun 2019, kepala Biro Analisis dan Kajian Strategi Badan Pendidikan Dan Pelatihan Pusat DPP PDI Perjuangan mengatakan sebagai berikut: "Media itu dipercaya sebagai gelar tempat dari demokrasi bagaimanapun dia seharusnya dan mudah-mudahan masih ya walaupun kita tahu tidak semua media seperti itu karena media tergantung pemiliknya padahal seharusnya media netral. Nah tentu saja kita menyampaikan kepada seluruh media apa-apa yang baik namun kadang dimedia tuh ada yang namanya tuh bad news is a good news. Semua media diundang semua lalu kita sampaikan data dan fakta terserah mereka menyampaikan dan mmengolah seperti apa ya itu urusan mereka kita tidak bisa mengatur (Utomo, wawancara, 2021)."

Pada kenyataannya, sangat dimungkinkan bahwa informasi yang diberitakan tidak sesuai dengan kenyataan objektifnya. Informasi yang diberikan bisa saja direkayasa sedemikian rupa untuk menguntungkan pihak-pihak tertentu yang menjadi afiliasi media massa bersangkutan. Media massa bukanlah institusi yang kebal terhadap kepentingan. Memang secara hakiki media massa harus berfungsi sebagai pemberi informasi yang berguna bagi masyarakat. Tetapi realitas menuntut banyak hal.

Terlepas bagaimana keadaan media, PDI Perjuangan memberikan informasi yang benar berdasarkan data dan fakta (Utomo, wawancara). Partai politik bertanggung jawab pula untuk memberikan informasi yang benar (Firmansyah, 2010). Kalau tidak, masyarakat akan menjadi korban pemberitaan media massa.

\section{SIMPULAN}

Pada pelaksanaan debat calon presiden dalam pemilihan presiden Tahun 2019 strategi kampanye politik yang diterapkan PDI Perjungan untuk mendukung Joko Widodo dan Ma'ruf Amin salah satunya adalah pemasaran produk politik melalui media massa (pull political marketing). Strategi pull marketing menitikberatkan pada pembentukan image politik yang positif. Hal-hal yang dilakukan oleh partai PDI perjuangan dalam hal ini yaitu: Pertama, melakukan penguatan substansi pada materi debat dengan membentuk tim dan meminta penbisa para ahli. Kedua, melakukan pengamatan terhadap target serta menentukan target terhadap debat politik. Ketiga, melakukan pendekatan yang baik terhadap media.

\section{DAFTAR PUSTAKA}

Ahmad, D, (2009), Iklan Politik TV, Modernisasi Kampanye Politik Pasca Orde Baru, Yogyakarta: LKis.

Arrianie, L. (2010). Komunikasi Politik Politisi dan Pencitraan di Panggung Politik. Bandung: Widya Padjajaran.

Creswell, J.W. (2010). Research design: pendekatan kualitatif, kuantitatif, dan mixed. Yogjakarta: PT Pustaka Pelajar.

Darma, A. (2009), Analisis Wacana Kritis, Bandung: Yayasan Widya bekerja sama dengan Jurusan Pendidikan Bahasa dan Sastra UPI.

Firmanzah. (2010). Persaingan, Legitimasi Kekuasaan, dan Marketing Politik. Jakarta: Yayasan Obor Indonesia.

Firmanzah. (2012). Marketing Politik .Jakarta: Pustaka Obor Indonesia.

Hasil Wawancara dengan Setio Utomo Kepala Biro Analisis Dan Kajian Strategi Badan Pendidikan Dan Pelatihan Pusat DPP PDI Perjuangan tertanggal 13 Juli 2021 pukul 11.30 WIB

Lilleker, D. G. (2006). Key Concepts in Political Communication. London: Sage Publications.

Mas'oed, M. \& Colin M. A. (1982). Perbandingan Sistem Politik, Yogyakarta: Gajah Mada University Press.

Mc. Nair, Brian. (2011). An Introduction to Political Communication (Fifth Edition). Routledge. London.

Mulyana, D. (2010). Metode Penelitian Kualitatif. Bandung: PT. Remaja Rosdakarya

Nyoman, Y. S. (2010). Pengaruh Tayangan Debat Capres dan Cawapres Dengan Keputusan Memilih Capres pada Pilpres 2009. Surabaya: Universitas 17 Agustus 
Perloff, R. M. (1998). Political Communication; Politic, Press and Public in America. New Jersey: Lawrence Erlbaum.

Rahman, A. H.. (2007). Sistem Politik Indonesia. Yogyakarta: Graha Ilmu.

Siti F. (2018), Kampanye sebagai Komunikasi Politik: Esensi dan Strategi dalam Pemilu, Wonosobo: Resolusi

Suara News. (2019). Jokowi Diprediksi Mampu Merebut Suara Pemilih yang Belum Menentukan Pilihan. Diunduh di https://www.suara.com/news/2019/03/13 /221958/jokowi-diprediksi-mampumerebut-suara-pemilih-yang-belummenentukan-pilihan tanggal 10 Juni 2021.

Tempo. (2019) "Jadwal Lengkap dan Tema Debat Pilpres 2019”, Koran Tempo 31 Januari 2019. Diakses pada https://tirto.id/jadwal-
lengkap-dan-tema-debat-pilpres-2019-dc6A tanggal 12 Desember 2020 pukul 16.42

Wahid, U. (2016). Komunikasi Politik teori, Konsep dan Aplikasi. Bandung: Simbiosa Rekatama Media.

Wulandari, R. (2013). Strategi Kampanye Politik Koalisi Partai Pengusung Afi-Mukmin Dalam Pemilihan Gubernur Tahun 2013. Diakses pada ejournal.ilkom.fisip-unmul.ac.id tanggal 16 Januari 2021 pukul 1.05 WIB

Yanto, Y. Strategi Kampanye Politik Calon Anggota Legislatif Incumbent Dewan Perwakilan Rakyat Daerah Dalam Menghadapi Pemilu Legislatif 2014 (Studi Kasus Partai Golkar Di Kabupaten Mukomuko). Professional: Jurnal Komunikasi dan Administrasi Publik, 1(2), 547-161. 